\title{
Effect of soil-spraying time on root-colonization ability of antagonistic Streptomyces griseoviridis
}

\author{
Hanna Kortemaa \\ Department of Plant Biology, Plant Pathology, PO Box 28, FIN-00014 University of Helsinki, Finland. \\ Current address: KTTK, Seed Testing Department, PO Box 111, FIN-32201 Loimaa, Finland, \\ e-mail: hanna.kortemaa@mmm.fi \\ Kielo Haahtela \\ Department of Biosciences, Division of General Microbiology, PO Box 56, FIN-00014 University of \\ Helsinki, Finland \\ Aino Smolander \\ Vantaa Research Centre, Finnish Forest Research Institute, PO Box 18, FIN-01301 Vantaa, Finland
}

\begin{abstract}
The root-colonization ability of Streptomyces griseoviridis Anderson et al. was tested on turnip rape (Brassica rapa subsp. oleifera DC.) and carrot (Daucus carota L.) by the sand-tube method. Nonsterile sand was sprayed with a microbial suspension immediately or 7 days after the seed had been sown. Results expressed as population frequencies and densities indicated that $S$. griseoviridis effectively colonizes the rhizosphere when the microbe is applied immediately after sowing but less effectively when it is applied 7 days later. Detection values of $S$. griseoviridis were higher for turnip rape than for carrot. In sterile sand, $S$. griseoviridis invaribly colonized the rhizosphere of turnip rape after each of the two applications. These findings indicate that $S$. griseoviridis can compete with indigenous soil microbes in the rhizosphere if it is sufficiently abundant in the soil before the seed emerges. If applied later, however, it competes rather poorly. In root-free nonsterile sand, S. griseoviridis dispersed and survived well.
\end{abstract}

Key words: actinomycetes, biological control, Brassica rapa ssp. oleifera, Daucus carota, plant growthpromoting rhizobacteria (PGPR), rhizosphere

\section{Introduction}

S. griseoviridis, a biocontrol agent used against some seed-borne and soil-borne plant pathogens (Tahvonen 1988), produces the auxin indole-3- acetic acid (IAA). The concentration of IAA produced on solid media by $S$. griseoviridis is of the same magnitude as that reported to have a growth-promoting effect (Tuomi et al. 1994). Mycostop (Kemira Oy, Finland) is a biofungicide produced by fermentation of the spores and 


\section{AGRICULTURAL AND FOOD SCIENCE IN FINLAND}

Kortemaa, H. et al. Effect of soil-spraying time on Streptomyces griseoviridis

mycelium of a $S$. griseoviridis strain isolated from peat by Tahvonen (1982).

Several isolates of Streptomyces spp., including the $S$. griseoviridis isolated from peat, produce polyene antibiotics. In contrast to nonsuppressive isolates most of the suppressive isolates produce a candicidin-type antibiotic (Raatikainen et al. 1993). Scanning electron microscopy studies show that $S$. griseoviridis is a hyperparasite of various plant pathogenic fungi (Tapio and Pohto-Lahdenperä 1991). Besides antibiosis and parasitism, competition is often mentioned as a mechanism of biocontrol. According to Sivan and Chet (1989), the inhibition of germination of chlamydospores might be due to competition between Trichoderma harzianum Rifai and Fusarium oxysporum Schlecht.: Fr. Rothrock and Gottlieb (1984), on the other hand, showed that the antagonism of $S$. hygroscopicus var. geldanus was due to the antibiotic production, not to competition for nutrients.

Microbes that colonize roots are ideal for use as biocontrol agents against soil-borne diseases (Weller 1988). Because soil spraying, like seed dressing is, an application method that has resulted in good biocontrol, our objective was to study how roots of turnip rape and carrot are colonized after soil-spraying treatment and to test whether application time has any effect on root colonization. We tested the root-colonization ability in both nonsterile and sterile sand to establish the effect of microbial competition in the rhizosphere on the colonization potential. As well as the growth of $S$. griseoviridis in the rhizosphere, we examined the dispersal of this antagonist in root-free sand.

\section{Material and methods}

\section{Root colonization in nonsterile sand}

The dispersal of $S$. griseoviridis in the rhizosphere was tested by the sand-tube method as described by Ahmad and Baker (1987) and Kor- temaa et al. (1994). Seeds of turnip rape, Brassica rapa subsp. oleifera cv. Kulta, and carrot, Daucus carota cv. Nantes Fancy, were surfacesterilized with ethanol and sodium hypochlorite $(\mathrm{NaOCl})$ as described by Kortemaa et al. (1994). PVC-plastic tubes $20 \mathrm{~cm}$ long and $3.2 \mathrm{~cm}$ in diameter were longitudinally sliced and fastened together with rubber bands. The tubes were blocked at the bottom with cotton wool and filled with nonsterile, sieved $(0.5-1.2 \mathrm{~mm})$ sand $(\mathrm{pH}$ 6.2 ). The sand, water and water-soluble fertilizer were mixed as described earlier, resulting in a water potential of $-1 \mathrm{kPa}$ (Kortemaa et al. 1994). One surface-sterilized seed was sown in each tube, and the tubes were placed vertically, five per each plastic pot containing the same sand mixture. A microbial suspension was prepared of Mycostop biofungicide as a $0.01 \%$ suspension in water. The average colony-forming unit (cfu) value of $S$. griseoviridis of the suspension detected on semi-selective water agar with glycerol (Kortemaa et al. 1994) was $8 \times 10^{4} \mathrm{ml}^{-1} ; 5 \mathrm{ml}$ of this microbial suspension was spread evenly with a pipette on the sand surface in each tube immediately after sowing (day 0 ) or was applied 7 days after sowing. The pots were covered with plastic bags, and no water was added after sowing. The pots were incubated for 4 weeks in a growth chamber ( $16 \mathrm{~h}$ light period, light intensity $150 \mathrm{mMols}^{-1} \mathrm{~m}^{-2}$ at $20^{\circ} \mathrm{C}$ and $8 \mathrm{~h}$ dark period at $\left.18^{\circ} \mathrm{C}\right)$.

After 4 weeks, the tubes were opened, and the roots were cut into $2 \mathrm{~cm}$ segments. The sand adhering to the root segments was considered as rhizosphere soil. For population-density counts, the cfu values were determined by a dilutionplating method on water-agar plates, although this method did not permit population densities lower than $10^{2} \mathrm{cfu} \mathrm{g}^{-1}$ soil to be detected. Sandfree root segments and above-ground portions of seedlings, i.e. stems and leaves, were placed on water-agar plates to isolate $S$. griseoviridis.

Root-colonization frequencies were counted for root segments and the rhizosphere, and the population density was counted as $\mathrm{cfu}^{-1}$ rhizosphere soil. Each experiment comprised 10 plants of turnip rape and carrot and the two application 
Vol. 6 (1997): 341-348.

times for the suspension. Five control plants were not treated. The experiment was conducted three times.

\section{Root colonization in sterile sand}

For this experiment, turnip rape was grown in sterile sand in a large glass pot containing four longitudinally sliced tubes. The sand was sterilized for $1 \mathrm{~h}$ and other material for $20 \mathrm{~min}$ at $121^{\circ} \mathrm{C}$ in an autoclave. A water suspension of $S$. griseoviridis, which had grown for 7 days on glucose-yeast-malt agar (GYM) (Kortemaa et al. 1994), was prepared for the spraying treatment instead of Mycostop suspension. The average population density of the suspension, which mainly consisted of spores of $S$. griseoviridis, was $6.5 \times 10^{6} \mathrm{cfu} \mathrm{ml}^{-1}$. For these experiments, the sterile seed was sown, the sand-tubes were incubated, and $S$. griseoviridis was applied and isolated as described above. The only exception was that for population density counts the microbe was isolated in the same manner for one tube in each pot on water-agar and GYM-agar plates to ensure that the sand was not contaminated with other microbes. Each experiment contained one untreated control pot and three pots with the two application times of the $S$. griseoviridis suspension. The experiment was conducted twice.

\section{Dispersal in nonsterile sand without plants}

For this experiment a large plastic box $(40 \mathrm{~cm} \mathrm{x}$ $60 \mathrm{~cm}$ ) and 32 plastic tubes were filled with the nonsterile sand-water-fertilizer mixture described above. The tubes were placed randomly in the box in a vertical position. Five millilitres of $0.01 \%$ Mycostop suspension was pipetted evenly onto the surface of each sand-tube; after this treatment, the tubes were not watered. The average population density of the suspension was $3 \times 10^{4} \mathrm{cfu} \mathrm{ml}^{-1}$. The box with the sand tubes, which was covered to avoid loss of moisture, was incubated in a growth chamber under the conditions described above for 4 weeks. Each week (7, 14, 21 and 28 days after treatment), eight tubes were randomly taken as a sample for measurements of population frequencies and densities at different depths of sand. The soil for these counts was sampled at every $2 \mathrm{~cm}$ between 0 and $12 \mathrm{~cm}$ from the top of the tube. The population density was counted by the dilution-plate method on water-agar plates. The experiment was conducted twice.

\section{Statistical analysis}

Cfu values were logarithmically transformed before analyses of variance [PROC GLM (SAS Institute Inc. 1988)]. Tukey's Studentized Range (HSD) Test was used to compare significantly different means.

\section{Results}

\section{Root colonization in nonsterile and sterile sand}

When Mycostop suspension was sprayed immediately (day 0) after sowing, the root-colonization frequencies on the roots and rhizosphere of turnip rape and carrot were higher than when the suspension was applied 7 days after sowing (Table 1). The frequency values were higher for turnip rape than carrot. The stems and leaves of turnip rape seedlings were colonized $100 \%$ after 0 and $73 \%$ after 7 days of treatment. For carrots, the corresponding values were $77 \%$ and $54 \%$.

The differences in population density values between the two applications were significant $(\mathrm{P}=0.05)$ at all root depths in the rhizosphere soil (Table 2). At a distance of $0-2 \mathrm{~cm}$ from the seed, the differences were significant between both treatments and plant species. 


\section{AGRICULTURAL AND FOOD SCIENCE IN FINLAND}

\section{Kortemaa, H. et al. Effect of soil-spraying time on Streptomyces griseoviridis}

Table 1. Root-colonization frequency of Streptomyces griseoviridis on root segments and in rhizosphere of turnip rape (Brassica rapa subsp. oleifera) and carrot (Daucus carota) after two different spraying times of Mycostop suspension in nonsterile sand.

\begin{tabular}{|c|c|c|c|c|}
\hline \multirow[b]{3}{*}{ Depth $(\mathrm{cm})$} & \multicolumn{4}{|c|}{ Root-colonization frequency (\%) } \\
\hline & \multicolumn{2}{|c|}{ Root $^{3}$} & \multicolumn{2}{|c|}{ Rhizosphere ${ }^{b}$} \\
\hline & day $0^{c}$ & day $7^{d}$ & day 0 & day 7 \\
\hline \multicolumn{5}{|l|}{ Brassica } \\
\hline $0-2$ & $100(30)^{e}$ & $100(30)$ & $100(30)$ & $100(30)$ \\
\hline $2-4$ & $100(29)$ & 47 (30) & $100(29)$ & $47(30)$ \\
\hline $4-6$ & $100(24)$ & $10(27)$ & $100(24)$ & $10(27)$ \\
\hline $6-8$ & 83 (19) & $18(19)$ & 83 (19) & 23 (19) \\
\hline $8-10$ & $85(14)$ & $0(15)$ & $85(14)$ & $0(15)$ \\
\hline \multicolumn{5}{|l|}{ Daucus } \\
\hline $0-2$ & 97 (29) & $51(28)$ & 97 (29) & $61(28)$ \\
\hline $2-4$ & $83(29)$ & $4(25)$ & $83(29)$ & $7(25)$ \\
\hline $4-6$ & $82(25)$ & $0(24)$ & $82(25)$ & $0(24)$ \\
\hline $6-8$ & $65(17)$ & $0(11)$ & 64 (17) & $0(11)$ \\
\hline $8-1$ & $23(10)$ & $0 \quad(8)$ & $22(10)$ & $0 \quad(8)$ \\
\hline
\end{tabular}

a $S$. griseoviridis isolated from root segments.

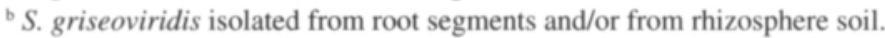

' Suspension sprayed on day 0 after sowing.

d Suspension sprayed on day 7 after sowing.

${ }^{e}$ Number of samples studied (n).

The rhizosphere of turnip rape was effectively colonized by $S$. griseoviridis in sterile sand. The results for the dilution series on GYM agar showed that the sand remained uncontaminated during the experiments. The root-colonization frequencies were $100 \%$. Population densities were high, and there were no significant differences between treatments (Table 3 ). The stems and leaves of turnip rape seedlings were colonized $66 \%$ and $75 \%$ after the 0 day and the 7 day treatments.

Table 2. Population densities (cfu values) of Streptomyces griseoviridis in rhizosphere of turnip rape (Brassica rapa subsp. oleifera) and carrot (Daucus carota) after two different spraying times of Mycostop suspension in nonsterile sand.

\begin{tabular}{|c|c|c|c|c|c|}
\hline \multirow[b]{2}{*}{ Treatment } & \multicolumn{5}{|c|}{$\begin{array}{c}\text { Population density }(\mathrm{cfu}) 10^{2} \mathrm{~g}^{-1} \text { of soil } \\
\text { Depth }(\mathrm{cm})\end{array}$} \\
\hline & $0-2$ & $2-4$ & 4-6 & 6-8 & $8-10$ \\
\hline \multicolumn{6}{|l|}{ Brassica } \\
\hline day 0 & $11000^{\mathrm{a}}$ & $2800^{\mathrm{a}}$ & $5300^{2}$ & $1000^{\circ}$ & 350 \\
\hline day 7 & $3100^{b}$ & $510^{b}$ & $1100^{b}$ & $3^{b}$ & nd \\
\hline \multicolumn{6}{|l|}{ Daucus } \\
\hline day 0 & $530^{\circ}$ & $<1$ & $270^{a}$ & $<1$ & $<1$ \\
\hline day 7 & $220^{4}$ & $<1$ & nd & nd & nd \\
\hline
\end{tabular}

Means within a column followed by the same letter were not significantly different according to Tukey's Studentized Range (HSD) Test $(\mathrm{P}=0.05)$, nd: not detected 
Vol. 6 (1997): 341-348.

Table 3. Population densities (cfu values) of Streptomyces griseoviridis in rhizosphere of turnip rape (Brassica rapa subsp. oleifera) after two spraying times of spore suspension on sterile sand.

\begin{tabular}{|c|c|c|c|c|c|}
\hline \multirow[b]{2}{*}{ Treatment } & \multicolumn{5}{|c|}{$\begin{array}{l}\text { Population density }(\mathrm{cfu}) 10^{2} \mathrm{~g}^{-1} \text { of soil } \\
\text { Depth }(\mathrm{cm})\end{array}$} \\
\hline & $0-2$ & $2-4$ & 4-6 & 6-8 & $8-10$ \\
\hline day 0 & 39000 & 23000 & 5600 & 7700 & 920 \\
\hline day 7 & 79000 & 42000 & 13000 & 4000 & 1900 \\
\hline
\end{tabular}

Means were not significantly different according to Tukey's Studentized Range (HSD) Test ( $\mathrm{P}=0.05)$.

\section{Dispersal in nonsterile sand without plants}

S. griseoviridis dispersed well in root-free sand when $5 \mathrm{ml}$ of Mycostop suspension was sprayed on the surface of the sand. The isolation frequencies of $S$. griseoviridis had already reached almost $100 \%$ at a depth of $0-6 \mathrm{~cm}$ from the top 7 days after inoculation (Fig. 1), and continued to accumulate over the next 2 weeks (14 and 21 days after treatment).

The population densities of $S$. griseoviridis isolated from different depths in the sand tube were highest at the top and decreased with depth (Fig. 2). The population of $S$. griseoviridis was stable during the experiment; differences in pop- ulation densities between sampling days were not significant $(\mathrm{P}=0.05)$ for any depth category.

\section{Discussion}

Root colonization was more effective when $S$. griseoviridis was applied to nonsterile sand immediately after sowing than when it was applied 7 days later, probably because during those days the rhizosphere was colonized by other soil microbes with which $S$. griseoviridis was unable to compete. The results of sterile-sand experiments, in which the rhizosphere was $100 \%$ col-
Fig. 1. Accumulation of isolation frequencies of Streptomyces griseoviridis at different soil depths during 28 days after spraying of Mycostop suspension on root-free sand.

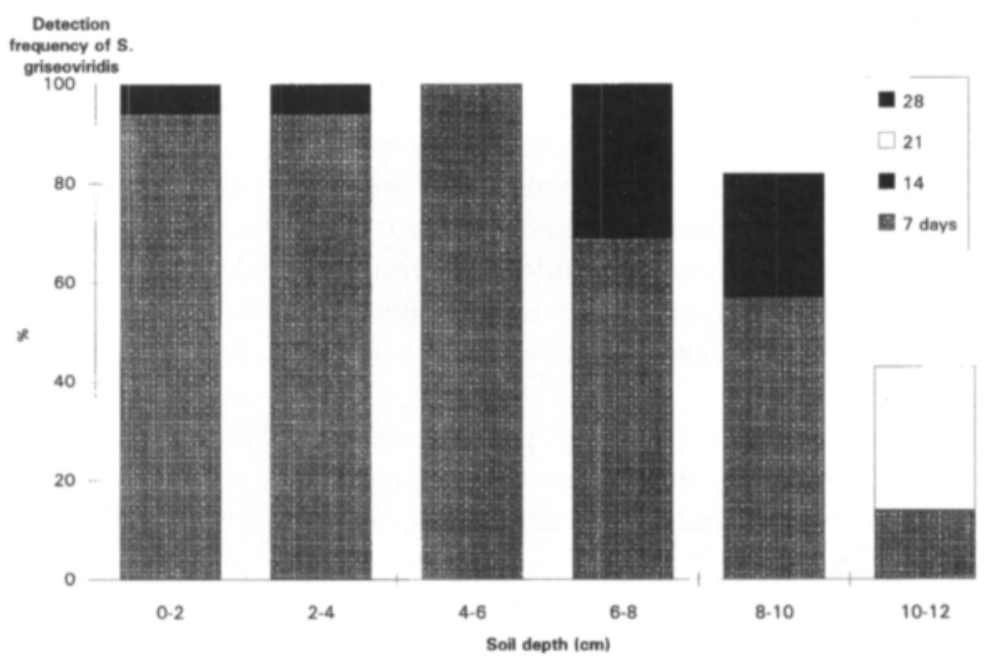




\section{AGRICULTURAL AND FOOD SCIENCE IN FINLAND}

\section{Kortemaa, H. et al. Effect of soil-spraying time on Streptomyces griseoviridis}

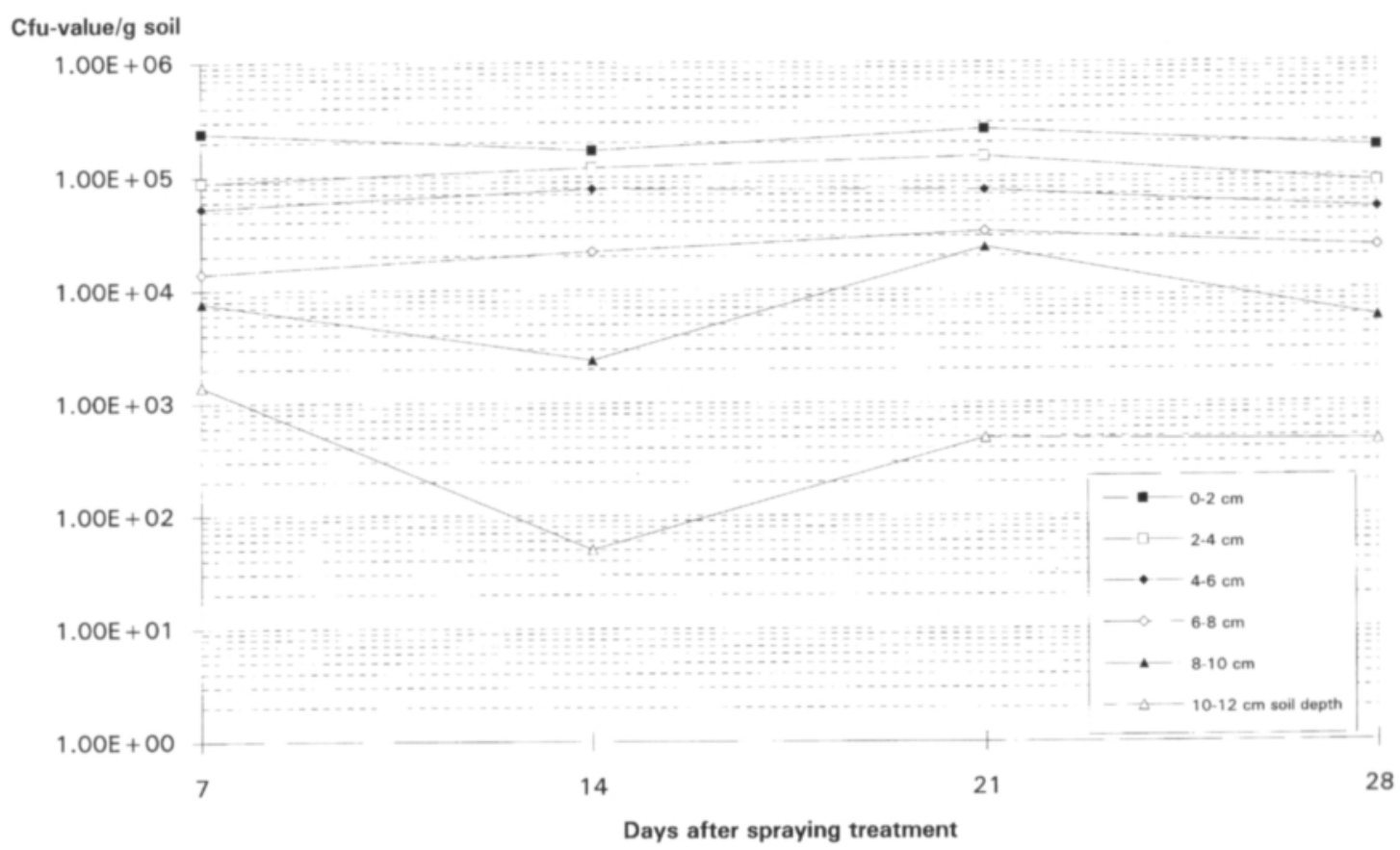

Fig. 2. Population densities (cfu values) of Streptomyces griseoviridis at different soil depths during 28 days after spraying of Mycostop suspension on root-free sand. Differences in population densities between sampling days were not significant $(\mathrm{P}=0.05)$ for any depth category.

onized by $S$. griseoviridis after both treatment times, support this contention. The higher population densities in sterile than in nonsterile sand are probably due to the higher inoculation densities and lack of competition with other microbes in sterile sand. The number of micro-organisms in nonsterile sand was probably rather low, and the absence of many of the microbes, both plant-growth-promoting and deleterious strains, to be found in soil with abundant organic material most likely affected competition. Scher et al. (1984) noted that microbial competition negatively affects the root-colonization capacity of fluorescent pseudomonads in nonsterile soil.

Isolation frequencies and population densities were greater for turnip rape than for carrot because the root exudates of turnip rape were probably more abundant or more available than those of carrot. The same results were obtained in our previous study (Kortemaa at el. 1994) us- ing the plate test. Sterile plants of turnip rape and carrot inoculated with $S$. griseoviridis were grown on water-agar plates. The difference in root colonization between the two plant species was clear. Without the effect of other microbes, the difference between plant species was suggested to be of plant origin, i.e. due to root exudates or morphological differences.

In both plant species the upper part of the root was more frequently colonized by $S$. griseoviridis than the lower parts. The population densities in the rhizosphere of turnip rape were higher than in the root-free sand experiment but population densities were lowest in the carrot rhizosphere. The results are similar to those of our previous studies, which were done using other application methods (Kortemaa et al. 1994, 1997). All these differences were probably due to root exudates (Curl and Truelove 1986)

The soil-spraying treatment method used here resulted in better dispersal in sand than did seed 


\section{AGRICULTURAL AND FOOD SCIENCE IN FINLAND}

Vol. 6 (1997): 341-348.

treatment (Kortemaa et al. 1994). Root-colonization was best when the $S$. griseoviridis suspension was mixed into the sand before sowing (Kortemaa et al. 1997). After seed treatment, the antagonist must actively colonize the rhizosphere with the aid of the root and seed exudates. After the soil-spraying treatment the antagonist dispersed well as shown by the experiment without plants, the antagonist being available all around the root. Seven days after seed sowing, the rhizosphere was mainly colonized by other soil microbes and $S$. griseoviridis was not able to colonize the rhizosphere effectively.

Our results suggest that $S$. griseoviridis can compete with indigenous soil microbes in the rhizosphere if it is well established in the sand before the seed emerges. If applied to the rhizosphere later, however, it competes rather poorly with other microbes. According to Lacey (1973), Streptomyces spp. colonize new substrates more slowly than do other bacteria and fungi. Our findings suggest that competition is probably not the main mode of action of antagonistic S. griseoviridis.

S. griseoviridis was isolated in great numbers in root-free sand with very little organic material. The antagonist survived well in rootfree sand after the suspension had been mixed into the sand (Kortemaa et al. 1997). Hatzinger and Alexander (1994) showed that the bacteria which survived well in nonsterile soil were present in the highest population densities in the rhizosphere. Bahme and Schroth (1987) noted that the bacteria which survived in nonrhizosphere soil have good potential as biocontrol agents because the bacteria can await the emerging seed in the soil. According to Wellington et al. (1990), populations of $S$. lividans and $S$. violaceolatus remain constant or decline in natural soil, and after a short mycelial growth phase, sporulation occurs and inoculants survive in the soil as spores.

Mohammadi and Lahdenperä (1994) found that seed dressing controls Rhizoctonia solani Kühn on cauliflower more effectively than does soil spraying or the mixing of Mycostop suspension into the growth substrate. On the other hand, soil-spraying treatment resulted in better cucumber seed emergence and a better gerbera flower yield than did other methods. According to ElAbyad et al. (1993) seed-coating treatment with antagonistic Streptomyces spp. was a more effective way of controlling various tomato pathogens than was soil inoculation. These results together with those of the present study support the idea that both timing and application method must be right if effective biocontrol is to be achieved with $S$. griseoviridis.

The dispersal of $S$. griseoviridis after soilspraying treatment was effective in both the rhizosphere and root-free sand. The root-colonization ability of the antagonist depended on the application time. $S$. griseoviridis could not compete effectively with indigenous soil microbes, and the rhizosphere was effectively colonized only if the sand was treated immediately after sowing.

Acknowledgements. We thank Tuula Laine and Lahja Pesonen for their technical assistance.

\section{References}

Ahmad, J.S. \& Baker, R. 1987. Rhizosphere competence of Trichoderma harzianum. Phytopathology 77 : 182189.

Bahme, J.B. \& Schroth, M.N. 1987. Spatial-temporal colonization patterns of a rhizobacterium on underground organs of potato. Phytopathology 77: 10931100.

Curl, E.A. \& Truelove, B. 1986. The rhizosphere. Springer-Verlag, Berlin, Germany. 288 p.
El-Abyad, M.S., El-Sayed, M.A., El-Shanshoury, A.R. \& El-Sabbagh, S.M. 1993. Towards the biological control of fungal and bacterial diseases of tomato using antagonistic Streptomyces spp. Plant and Soil 149: $185-195$.

Hatzinger, P.B. \& Alexander, M. 1994. Relationship between the number of bacteria added to soil or seeds and their abundance and distribution in the rhizosphere of alfalfa. Plant and Soil 158: 211-222. 


\title{
AGRICULTURAL AND FOOD SCIENCE IN FINLAND
}

Kortemaa, H. et al. Effect of soil-spraying time on Streptomyces griseoviridis

Kortemaa, H., Pennanen, T., Smolander, A. \& Haahtela, K. 1997. Distribution of antagonistic Streptomyces griseoviridis in rhizosphere and non-rhizosphere sand. Journal of Phytopathology 145: 137-143.

- , Rita, H., Haahtela, K. \& Smolander, A. 1994. Rootcolonization ability of antagonistic Streptomyces griseoviridis. Plant and Soil 163: 77-83.

Lacey, J. 1973. Actinomycetes in soils, composts and fodders. In: Sykes, G. \& Skinner, F.A. (eds.). Actinomycetales: Characteristics and practical importance. Academic Press, London. p. 231-251.

Mohammadi, O. \& Lahdenperā, M.L. 1994. Impact of application method on efficacy of Mycostop biofungicide. In: Ryder, M.H. et al. (eds.). Improving plant productivity with rhizosphere bacteria. Proceedings of the Third International Workshop on Plant GrowthPromoting Rhizobacteria. CSIRO, Australia. p. 279281.

Raatikainen, O., Tuomisto, J., Tahvonen, R. \& Rosenqvist, H. 1993. Polyene production of antagonistic Streptomyces species isolated from Sphagnum peat. Agricultural Science of Finland 2: 551-561.

Rothrock, C.S. \& Gottlieb, D. 1984. Role of antibiosis of Streptomyces hygroscopicus var. geldanus to Rhizoctonia solani in soil. Canadian Journal of Microbiology 30: 1440-1447.

SAS Institute Inc. 1988. SAS/STAT user's guide. Release 6.03. Cary, USA. 1028 p.

Scher, F.M., Ziegle, J.S. \& Kloepper, J.W. 1984. A meth- od for assessing the root-colonizing capacity of bacteria on maize. Canadian Journal of Microbiology 30 : 151-157.

Sivan, A. \& Chet, I. 1989. The possible role of competition between Trichoderma harzianum and Fusarium oxysporum on rhizosphere colonization. Phytopathology 79: 198-203.

Tahvonen, R. 1982. The suppressiveness of Finnish light coloured Sphagnum peat. Journal of the Scientific Agricultural Society of Finland 54: 345-356.

- 1988. Microbial control of plant diseases with Streptomyces spp. EPPO Bulletin 18: 55-59.

Tapio, E. \& Pohto-Lahdenperă, A. 1991. Scanning electron microscopy of hyphal interaction between Streptomyces griseoviridis and some plant pathogenic fungi. Journal of the Scientific Agricultural Society of Finland 63: 435-441.

Tuomi, T., Laakso, S. \& Rosenqvist, H. 1994. Indole-3acetic acid (IAA) production by a biofungicide Streptomyces griseoviridis strain. Annales Botani Fennici 31: $59-63$.

Weller, D.M. 1988. Biological control of soilborne plant pathogens in the rhizosphere with bacteria. Annual Review of Phytopatholology 26: 379-407.

Wellington, E.M.H., Cresswell, N. \& Saunders, V.A. 1990. Growth and survival of streptomycete inoculants and extent of plasmid transfer in sterile and nonsterile soil. Applied and Environmental Microbiology 56: 14131419.

\section{SELOSTUS}

\section{Kasvualustan käsittelyajan vaikutus Streptomyces griseoviridis -antagonistin juurten asutuskykyyn}

\author{
Hanna Kortemaa, Kielo Haahtela ja Aino Smolander \\ Helsingin yliopisto ja Metsäntutkimuslaitos
}

\begin{abstract}
Mikrobit, jotka asuttavat tehokkaasti juuria, ovat lupaavia biotorjuntaeliöitä käytettäväksi maalevintäisten kasvitautien torjuntaan. Antagonistisen Streptomyces griseoviridis -sädebakteerin kykyä asuttaa rypsin ja porkkanan juuria testattiin hiekkaputkimenetelmällä. Käsittelemätön hiekka kasteltiin mikrobiliuoksella joko välittömästi tai seitsemän vuorokauden kuluttua siemenen kylvöstä. Tulokset osoittivat, että $S$. griseoviridis asutti juurivyöhykkeen tehokkaasti, jos mikrobikäsittely tehtiin välittömästi kylvön jälkeen, mutta selvästi heikommin, kun käsittely tehtiin viikon kuluttua kylvöstä. Mikrobitiheydet olivat rypsin juuressa suuremmat kuin porkkanan juuressa. Antagonisti eristettiin juuren yläosasta useammin
\end{abstract}

kuin alemmista osista. Steriilissä hiekassa $S$. griseoviridis asutti rypsin juuret tehokkaasti molempien käsittelyaikojen jälkeen. Nämä tulokset osoittavat, että $S$. griseoviridis pystyy kilpailemaan maassa luontaisesti esiintyvien mikrobien kanssa, jos antagonistia on kasvualustassa runsaasti ennen siemenen itämistä. Jos antagonisti lisätään maahan myöhemmin, se pystyy suhteellisen huonosti kilpailemaan muiden mikrobien kanssa. Hyvän biotorjuntatuloksen saavuttaminen käytännön kasvintuotannossa edellyttää oikean käsittelymenetelmän ja -ajan tuntemista. $S$. griseoviridis levisi ja säilyi elävänä hyvin steriloimattomassa hiekassa, jossa ei kasvanut kasveja. 